\title{
Here are the polyps: in situ observations of jellyfish polyps and podocysts on bivalve shells
}

\author{
Lodewijk van Walraven $^{\text {Corresp., }}{ }^{\text {, Judith van Bleijswijk }}{ }^{2}$, Henk W van der Veer ${ }^{1}$ \\ ${ }^{1}$ Department of Coastal Systems, and Utrecht University, NIOZ Royal Netherlands Institute for Sea Research, Den Burg, Netherlands \\ 2 Department of Marine Microbiology and Biogeochemistry, and Utrecht University, NIOZ Royal Netherlands Institute for Sea Research, Den Burg, \\ Netherlands \\ Corresponding Author: Lodewijk van Walraven \\ Email address: lodewijk.van.walraven@nioz.nl
}

Most Scyphozoan jellyfish species have a metagenic life cycle involving a benthic, asexually reproducing polyp stage and a sexually reproducing medusa stage. Medusae can be large and conspicuous and most can be identified using morphological characteristics. Polyps on the other hand are small, live a cryptic life attached to hard substrates and often are difficult or impossible to distinguish based on morphology alone. Consequently, for many species the polyp stage has not been identified in the natural environment. We inspected hard substrates in various habitats for the presence of Scyphozoan polyps. Three polyps were found on Dogger Bank, Central North Sea, attached to the inside of the umbo of empty valves of the bivalves Mactra stultorum and Spisula subtruncata. . One polyp was accompanied by four podocysts. With this knowledge, the inside of bivalve shells washed ashore in Oostende (Belgium) was inspected and supposed podocysts on the inside of empty valves of Cerastoderma edule and Spisula elliptica were found. Polyps and podocysts were identified to species level by $18 \mathrm{~S}$ rDNA and mitochondrial COI sequencing. The three polyps found on Dogger Bank all belonged to the compass jellyfish Chrysaora hysoscella. One podocyst from the Oostende beach also belonged to this species but another podocyst belonged to Cyanea lamarkii. These are the first in situ observations of Chrysaora and Cyanea polyps and podocysts in the natural environment. Mactra, Cerastoderma and Spisula species are abundant in many North Sea regions and empty bivalve shells could provide an abundant settling substrate for jellyfish polyps in the North Sea and other areas. Several new strategies to increase the detection of polyps on bivalve shells are presented. 


\section{Here are the polyps: in situ observations of jellyfish}

2 polyps and podocysts on bivalve shells

3

4 Lodewijk van Walraven ${ }^{1}$, Judith van Bleijswijk ${ }^{2}$, Henk W. van der Veer ${ }^{1}$

5

$6 \quad{ }^{1}$ NIOZ Royal Netherlands Institute for Sea Research, Department of Coastal Systems, and

7 Utrecht University, P.O. Box 59, 1790 AB, Den Burg, Texel, The Netherlands

$8 \quad{ }^{2}$ NIOZ Royal Netherlands Institute for Sea Research, Department of Marine Microbiology and

9 Biogeochemistry, and Utrecht University, P.O. Box 59, 1790 AB, Den Burg, Texel, The

10 Netherlands

11

12 Corresponding Author:

13 Lodewijk van Walraven ${ }^{1}$

14 P.O. Box 59, 1790 AB, Den Burg, Texel, The Netherlands

15 Email address: Lodewijk.van.walraven@gmail.com

16 


\section{Abstract}

18 Most Scyphozoan jellyfish species have a metagenic life cycle involving a benthic, asexually reproducing polyp stage and a sexually reproducing medusa stage. Medusae can be large and conspicuous and most can be identified using morphological characteristics. Polyps on the other hand are small, live a cryptic life attached to hard substrates and often are difficult or impossible to distinguish based on morphology alone. Consequently, for many species the polyp stage has not been identified in the natural environment. We inspected hard substrates in various habitats for the presence of Scyphozoan polyps. Three polyps were found on Dogger Bank, Central North Sea, attached to the inside of the umbo of empty valves of the bivalves Mactra stultorum and Spisula subtruncata. One polyp was accompanied by four podocysts. With this knowledge, the inside of bivalve shells washed ashore in Oostende (Belgium) was inspected and supposed podocysts on the inside of empty valves of Cerastoderma edule and Spisula elliptica were found. Polyps and podocysts were identified to species level by $18 \mathrm{~S}$ rDNA and mitochondrial COI sequencing. The three polyps found on Dogger Bank all belonged to the compass jellyfish Chrysaora hysoscella. One podocyst from the Oostende beach also belonged to this species but another podocyst belonged to Cyanea lamarkii. These are the first in situ observations of Chrysaora and Cyanea polyps and podocysts in the natural environment. Mactra, Cerastoderma and Spisula species are abundant in many North Sea regions and empty bivalve shells could provide an abundant settling substrate for jellyfish polyps in the North Sea and other areas. Several new strategies to increase the detection of polyps on bivalve shells are presented.

\section{Introduction}

Most Scyphozoan jellyfish species have a metagenic life cycle involving sexually reproducing pelagic medusae producing planula larvae which settle into benthic polyps called scyphistomae, or podocysts (Fig. 1). Scyphistomae (hereafter called "polyps") can reproduce asexually in several ways including by strobilation, releasing juvenile jellyfish called ephyra into the water column (Adler and Jarms, 2009; Arai, 1997; Helm, 2018; Schiariti et al., 2014). Most species can also form podocysts, either directly from planula larvae or beneath polyp pedal discs. Podocysts have a chitinous outer layer and contain reserves which allow them to survive for longer periods in adverse conditions such as food scarcity or high predation pressure by nudibranchs (Arai, 2009; Boero et al., 2008; Holst, 2012; Lucas et al., 2012).

Polyps and podocysts are small, live a cryptic life attached to hard substrates and are difficult or impossible to distinguish based on their morphology alone. Consequently, despite the ecological importance of the polyp stage as the source of metagenic scyphozoan blooms (Arai, 1997; Boero et al., 2008; Helm, 2018; Lucas et al., 2012; Schiariti et al., 2014), for many species the polyp stage has not been observed in the natural environment (Van Walraven et al., 2016).

In Japanese waters polyps have been observed in situ for Aurelia species on artificial substrates (Makabe et al. 2014, Shibata et al. 2015) and Chrysaora pacifica polyps and podocysts have been found on shells and stones in dredge samples (Toyokawa 2011). 
57 For the North Sea area, it has long been suggested that benthic stages of scyphozoan jellyfish

58

59

60

61

62

63

64

65

66

67

68

69

70

71

72

73

74

75

76

77

78

79

80

81

82

83

84

85

86

87

88

89

90

91

92

93

94

95

should occur in the area, based on the observation of ephyrae (Van der Baan, 1980). In experiments, the five species occurring in the North Sea area, Aurelia aurita, Cyanea capillata, Cyanea lamarckii, Chrysaora hysoscella and Rhizostoma octopus have all been shown to produce planulae that settle on hard substrates and develop into polyps or podocysts (Holst, 2012; Holst and Jarms, 2007; Holst and Laakmann, 2014).

In a previous study, polyps were collected from natural and artificial substrates at various inshore and offshore locations in the North Sea and Sweden and could be identified to species level by sequencing both a fragment of $18 \mathrm{~S}$ rDNA and a fragment of mitochondrial COI (van Walraven et al., 2016). In this paper we continue our search for Scyphozoan benthic stages. We describe two promising, widely applicable approaches to find and identify polyps and podocysts on bivalve shells, which lead to the first in situ observation of benthic stages of Cyanea lamarckii and Chrysaora hysoscella are documented.

\section{Materials \& Methods}

Sampling. Benthic stages of jellyfish were sampled using two different methods. On a transect from Texel, the Netherlands to Fladen Grounds, Northern North Sea (Fig. 2), the Deep Digging Dredge ("Triple D dredge") was used to sample benthic fauna. The triple D dredge uses a $20 \mathrm{~cm}$ wide knife that cuts through the sediment to a depth of $20 \mathrm{~cm}$ over a distance of about $100 \mathrm{~m}$, sampling an area of $20 \mathrm{~m}^{2}$ (Bergman and van Santbrink, 1994; Witbaard et al., 2013). Sampling in UK waters was approved by the Maritime Policy Unit (Legal Directorate) of the Foreign and Commonwealth Office (ref 33/2018). Subsamples of the "bycatch" from the triple D samples; stones and empty bivalve shells, were collected and stored in seawater at $4{ }^{\circ} \mathrm{C}$. The stones and shells were inspected for the presence of scyphozoan benthic stages by visually examining the substrates submerged in seawater, illuminated with a cold light source. When scyphozoan benthic stages were found on Dogger Bank $(55.1711,3.1626)$ their presence was confirmed by inspection with a stereo microscope. Scyphozoan polyps were removed from the substrate using the tip of a flame-sterilised scalpel and stored in $95 \% \mathrm{EtOH}$ in $2 \mathrm{ml}$ Eppendorf vials prior to analysis.

Following the observation of podocysts on empty shells in the Dogger Bank samples, the question arose whether these podocysts would remain attached to the shells when they wash up on beaches. On 19-09-2018, empty bivalve shells were collected along the high-water line of Oostende beach, Belgium $(51.2338,2.9121)$. Shells were rinsed in seawater and were inspected by eye for the presence of scyphozoan podocysts. In the lab, shells were inspected under a stereomicroscope and podocysts were removed from the substrate using the tip of a flamesterilised scalpel dipped in $95 \% \mathrm{EtOH}$ to moisten the podocysts prior to removal, as it was found that dried podocysts would disintegrate or disperse when attempting to remove them. 
96

97

98

99

100

101

102

103

104

105

106

107

108

109

110

111

112

113

114

115

116

117

118

119

120

121

122

123

124

125

126

127

128

129

130

131

132

133

134

Podocyst- or polyp containing shells were photographed submerged using a Pentax K5 DSLR with Pentax D-FA $100 \mathrm{~mm}$ macro lens. Polyps and cysts were photographed using an Olympus stereomicroscope at 20x magnification using a Bresser Microkular ocular tube camera. Stereomicroscope photographs were used to measure polyps and podocysts in ImageJ (Schneider et al., 2012). Of each polyp/podocyst, the diameter was measured along the horizontal as well as the vertical axis.

Genetic analysis. In a dedicated DNA extraction (pre-PCR) lab, polyps and podocysts were transferred to a sterile Eppendorf vial with $200 \mu 1$ ethanol using a $1 \mathrm{ml}$ micropipette (large diameter of opening). After a short spin, most of the ethanol was removed with a $100 \mu 1$ micropipette, leaving about $20 \mu \mathrm{l}$ containing the polyps or podocysts. These were washed two times with $1 \mathrm{ml}$ of PCR grade water and resuspended in $20 \mu 1$ lysis buffer taken from the GenElute Mammalian Genomic DNA kit (Sigma). Samples were ground in the Eppendorf vial using a sterile plastic pestle (VWR, 431-0094). Subsequently, DNA isolation was carried out according to the manufacturer of the kit, involving an overnight lyses step at $53{ }^{\circ} \mathrm{C}$ and a final elution of the DNA from the silica column in $100 \mu \mathrm{l}$ Tris buffer $(10 \mu \mathrm{M})$.

DNA concentrations in the extracts were generally too low to be measured with a Qubit fluorimeter. Exceptions were polyp 1 and 2 and podocyst 7 with concentrations of $0.14,0.09$ and $0.04 \mathrm{ng} / \mathrm{ul}$ respectively corresponding to yields between 140 and $40 \mathrm{ng}$. In $50 \mu 1$ PCRs containing $2 \mu 1$ DNA extract, 1 unit of BiothermPlus polymerase (Genecraft), 1x buffer, $200 \mu \mathrm{M}$ dNTPs, and $0.5 \mu \mathrm{M}$ of each primer, diagnostic fragments of $18 \mathrm{~S}$ rRNA and $\mathrm{CO} 1$ were amplified. For $18 \mathrm{~S}$ rRNA we used primers EUK_F566 (5'-CAG CAG CCG CGG TAA TTC C-3') and EUK_R1200 (5'-CCC GTG TTG AGT CAA ATT AAG C-3') with an annealing temperature of $60^{\circ} \mathrm{C}$ in 35 cycles amplifying $650 \mathrm{nt}$ of the $\mathrm{V} 4$ and $\mathrm{V} 5$ region (Hadziavdic et al., 2014); for COI we used the jellyfish specific primers FFDL (5'-TTT CAA CTA ACC AYA AAG AYA TWG G-3') and FRDL2 (5'-TAN ACT TCW GGR TGN CCR AAG AAT CA-3') with an annealing temperature of $51^{\circ} \mathrm{C}$ in 39 cycles amplifying 709nt of COI (Armani et al., 2013). PCR protocols involved 2 minutes initial denaturation, followed by 35 or 39 cycles of 45 seconds denaturation at $95^{\circ} \mathrm{C}, 60$ seconds annealing at the temperatures indicated above, and 60 seconds extension at $72^{\circ} \mathrm{C}$. After a prolonged extension of 7 minutes at $72{ }^{\circ} \mathrm{C}$, and a cooling of 4 minutes at $4{ }^{\circ} \mathrm{C}$, the programme ended with a pause at $15^{\circ} \mathrm{C}$. Negative controls did not generate a band. PCR products were Sanger sequenced by BaseClear (Leiden) with forward and reverse primers, and consensus sequences were composed with Chromas Pro software.

Consensus sequences were submitted to GenBank and are available under accession numbers MT074030- MT074034 (COI) and MT075505-MT075509 (18S). The sequences were compared against the NCBI database Nucleotide collection (nr/nt) using BLASTn as a first identification step. Reference trees were built in ARB (Ludwig et al. 2004) using the RAxML tool version 8.2.11 (Stamatakis 2014) with sequences from jellyfish species available in GenBank. Newly 
135

136

137

138

139

140

141

142

143

144

145

146

147

148

149

150

151

152

153

154

155

156

157

158

159

160

161

162

163

164

165

166

167

168

169

170

171

172

173

174

obtained polyp and podocyst sequences were aligned with Fastaligner, and added to the reference tree using the ARB parsimony option.

\section{Results}

On Dogger Bank, polyps were found on shells of Spisula subtruncata and Mactra stultorum. On two $S$. subtruncata shells, a single polyp was found. On a $M$. stultorum shell, two polyps were found, with a calyx diameter of 0.31 and $0.90 \mathrm{~mm}$, the latter was accompanied by a cluster of four podocysts (Fig. 3). Podocysts had diameters of 0.34, 0.29 and $0.31 \mathrm{~mm}$ (average of 0.31), where one could not be measured as it was obscured by the polyp.

At Oostende beach, jellyfish podocysts were found on 23 shells of 7 species: Spisula subtruncata, Spisula solida, Spisula elliptica, Aequepecten opercularis, Mimachlamys varia, Donax vittatus, Acanthocardia echinata and Cerastoderma edule (Fig. 4). Both cysts and polyps were most often observed in or near the umbo of the shell, always on the inside.

Podocysts were generally circular in shape, with a smooth edge. Podocysts had a central depression, which had an even surface in some podocysts, but in others contained a circular hole, suggesting the podocyst was empty. Minimum podocyst diameter was $0.15 \mathrm{~mm}$, maximum podocyst diameter was $0.61 \mathrm{~mm}$, and average cyst diameter $(\mathrm{n}=71)$ was $0.31 \mathrm{~mm}$.

Polyps and podocysts were used entirely for genetic analyses. We were able to obtain amplicons from eleven specimens with the universal eukaryote $18 \mathrm{~S}$ rRNA gene primers, and amplicons from nine specimens with the COI primers. All amplicons $(n=20)$ were sent off for Sanger sequencing. Results with the universal 18S PCR yielded seven successful identifications: Five specimens came out as Scyphozoa: three polyp and one podocyst were identified as Chrysaora hysoscella and one additional podocyst was identified as Cyanea lamarkii (Table 1 and Figure 5). Two podocysts came out as non Scyphozoa: one as the fungus Phoma sp. and the other as the Rhodophyte Pyropia sp. All other sequences were not readable. Independent results with COI primers confirmed the identifications of the five Scyphozoa specimens (Figure 6). One presumed podocyst showed a low similarity ( $80 \%$ identical) to the Serpulid Hydroides sp. and sequences of three other specimens were unreadable.

Average sizes of the two podocyst clusters that could be identified to species level were $0.22 \mathrm{~mm}$ $(\mathrm{n}=10)$ for Cyanea lamarckii and $0.34 \mathrm{~mm}(\mathrm{n}=5)$ for Chrysaora hysoscella. These means were significantly different (one-way ANOVA, F $(1,13)=23.51, \mathrm{p}=0.0003181$ ).

Podocysts were often clustered together (Fig. 4). Some clusters had a zig-zag shape with cyst size increasing, such as clusters 1, 4 and 5. Other clusters had a more random shape, such as clusters 2 and 3. The maximum number of podocysts per cluster was 11 on a shell of Mimachlamys varia. The average number of podocysts on a shell was 15.7 , the minimum amount was 2 and the maximum amount was 75 podocysts on a single shell of Mimachlamys varia. 


\section{Discussion}

176 Previous work based on visual inspections of artificial and natural hard substrates for 177 scyphozoan benthic stages in the North Sea area (Van Walraven et al., 2016) uncovered only 178 polyps and podocysts of Aurelia aurita. Some of these polyps were also found on bivalves: 179 living bivalves of the species Heteranomia squamula (one site), Magallana gigas (three sites) 180 and Mytilus edulis (six sites). Polyp colonies sampled for this previous study were often large 181 and conspicuous, while the podocyst and polyp clusters documented in the present study were smaller and more cryptic. This suggests that scyphozoan species other than A. aurita might have benthic stages that are more cryptic and occupy different niches where they are difficult to find. Aurelia is widely distributed and highly invasive (Dawson, 2004; Bayha and Graham, 2014), and its widespread occurrence on anthropogenic substrates documented in van Walraven et al. 2016 might suggest it outcompetes other Scyphozoan species on these substrates. This might explain why for many species worldwide the benthic stages have never been observed in situ.

Chrysaora hysoscella podocysts from cultures are shown in Morandini and Marques (2010, figs. 34 and 35). These podocysts have a similar morphology, size and clustering as observed in our study. Similar podocyst colour and diameter are reported by Arai (Arai, 2009) as well. Podocysts can contribute significantly to the formation of scyphozoan jellyfish blooms. They can be dormant for more than a year, surviving conditions detrimental to polyps such as hypoxia, burial in sediment and extreme temperature or salinity (Arai, 2009, Kawahara et al. 2012, Thein et al. 2013). The observation of 75 podocysts on a single shell implies that one single bivalve shell could potentially be the source of several hundred ephyrae if all podocysts on a shell developed into polyps and these would all strobilate, considering that in experiments at $10^{\circ} \mathrm{C}$ Cyanea lamarckii polyps produced around 8 ephyrae per polyp in salinity levels encountered in the North Sea (Holst and Jarms, 2010).

200

201

202

203

204

205

206

207

In the North Sea, extensive oyster banks of Ostrea edulis occurred, which were decimated in the late $19^{\text {th }}$ and early $20^{\text {th }}$ century by oyster harvesting and bottom trawling (Gercken and Schmidt, 2014; Houziaux et al., 2011; Olsen, 1883). These oyster banks might have offered extensive habitat for scyphozoan polyps. The density of living non-reef forming bivalves can still be extremely high in the southern North Sea area. As an example, Spisula subtruncata has been observed in densities of several thousand ind $\mathrm{m}^{-2}$ in the coastal Dutch North Sea (de Bruyne et al., 2013; Perdon et al., 2018). The bivalve shells on which our polyps and podocysts were observed belong to species that are common in the southern North Sea/English Channel area (de Bruyne et al., 2013; Degraer et al., 2006; Perdon et al., 2018). Bivalve shells can thus be an important settling substrate for Scyphozoa in the North Sea area.

Biogenic, secundary hard substrates such as dead bivalve shells are found in freshwater and in brackish and marine ecosystems worldwide, as are organisms that colonise these, which are called "skeletobionts", "skeletophytes" for plants and "skeletozoans" for animals. Bivalves been observed to form important habitat islands for hard substrate colonisers in recent as well as in 
215 fossil soft sediments, as early as the Palaeozoic (Taylor and Wilson, 2003). Bivalves and

216 fossilised traces of Scyphozoan jellyfish appear in the fossil record around the same time, in the

217 early Cambrian (Hagadorn et al. 2002, Cartwright et al. 2007) making it likely that many

218 jellyfish species have evolved to use bivalve shells as substrate for their benthic stages.

219 Transportation of bivalves and other hard substrates could be an important vector of introduction

220 of invasive species of jellyfish, as has been found for the hydroid Gonionemus vertens

221 (Govindarajan and Carman, 2016). Detection of jellyfish benthic stages using barcoding can

222 increase our understanding of their dispersal and spread, for example through early detection of

223 invasions or by tracing back jellyfish blooms to their location of origin.

224

225

226

227

228

229

230

231

232

233

234

235

236

\section{Conclusions}

This study documents the first in situ observations of benthic stages of two scyphozoan species, Chrysaora hysoscella and Cyanea lamarckii, obtained from benthic dregdge samples and beaches. We show that podocysts are resilient enough to be detected in bivalve shells washed up on beaches, and that these washed up podocysts can still yield DNA for genetic species identification. Empty bivalve shells may also offer suitable settling substrate for other species of scyphozoa for which the benthic stage has not yet been found in situ. The preferred method to collect shells with identifiable podocysts or polyps on them would be to directly collect shells from the sediment surface, either by scuba diving or by collecting shells from the surface of sediment cores and subsequent preservation in $>80 \%$ ethanol. The methods documented here could be applied worldwide and may help to fill the knowledge gap on scyphozoan benthic stages that still exists for many species.

237

238

239

\section{Acknowledgements}

240

We would like to thank Marco Faasse for sharing his observations and insights on the possible whereabouts of scyphozoan polyps. We also thank the crew of RV Pelagia for their dedicated

242 assistance during sampling and Rob Witbaard for organising and leading the NICO10 expedition

243 leg. Hans Malschaert was valuable as Linux helpdesk. Finally, we thank Maartje Brouwer, Sanne Vreugdenhil and Kevin Sarelse for performing the lab work. Carolina Olguin Jacobson and two

245 anonymous reviewers provided constructive and detailed comments that improved the manuscript.

\section{References}

249

Adler, L., Jarms, G., 2009. New insights into reproductive traits of scyphozoans: special methods of propagation in Sanderia malayensis GOETTE, 1886 (Pelagiidae, Semaeostomeae) enable establishing a new classification of asexual reproduction in the class Scyphozoa. Mar. Biol. 156, 1411-1420. https://doi.org/10.1007/s00227-009-1181-6

Arai, M.N., 2009. The potential importance of podocysts to the formation of scyphozoan blooms: a review. Hydrobiologia 616, 241-246. 
255

256

257

258

259

260

261

262

263

264

265

266

267

268

269

270

271

272

273

274

275

276

277

278

279

280

281

282

283

284

285

286

287

288

289

290

291

292

Arai, M.N., 1997. A Functional Biology of Scyphozoa. Chapman \& Hall, London.

Armani, A., Tinacci, L., Giusti, A., Castigliego, L., Gianfaldoni, D., Guidi, A., 2013. What is inside the jar? Forensically informative nucleotide sequencing (FINS) of a short mitochondrial COI gene fragment reveals a high percentage of mislabeling in jellyfish food products. Food. Res. Int. 54, 1383-1393.

Bayha, K. M., \& Graham, W. M. 2014., Nonindigenous Marine Jellyfish: Invasiveness, Invasibility, and Impacts. In: Pitt, K. A. \& Lucas, C. H. (eds.) Jellyfish Blooms. Dordrecht: Springer Netherlands.

Bergman, M.J.N., van Santbrink, J.W., 1994. A new benthos dredge ('triple-D') for quantitative sampling of infauna species of low abundance. Neth. J. Sea Res. 33, 129-133.

Boero, F., Bouillon, J., Gravili, C., Miglietta, M.P., Parsons, T., Piraino, S., 2008. Gelatinous plankton: irregularities rule the world (sometimes). Mar Ecol Prog Ser 356, 299-310.

de Bruyne, R., van Leeuwen, S.J., Meyling, A.G., Daan, R., 2013. Schelpdieren van het Nederlandse Noordzeegebied. Ecol. Atlas Van Mariene Weekdieren Mollusca Tirion Uitgevers Utrecht En Sticht. Anemoon Lisse 414.

Cartwright, P., Halgedahl, S.L., Hendricks, J.R., Jarrard, R.D., Marques, A.C., Collins, A.G., Lieberman, B.S., 2007. Exceptionally Preserved Jellyfishes from the Middle Cambrian. PLOS ONE 2, e1121.

Dawson, M. N. 2004. Macro-morphological variation among cryptic species of the moon jellyfish, Aurelia (Cnidaria: Scyphozoa). Mar. Biol., 144, 203-203.

Degraer, S., Wittoeck, J., Appeltans, W., Cooreman, K., Deprez, T., Hillewaert, H., Hostens, K., Mees, J., Vanden Berghe, E., Vincx, M., 2006. De macrobenthosatlas van het Belgisch deel van de Noordzee.

EMODnet Bathymetry Consortium, 2016. EMODnet Digital Bathymetry (DTM). http://doi.org/10.12770/c7b53704-999d-4721-b1a3-04ec60c87238

Gercken, J., Schmidt, A., 2014. Aktueller Status der Europäischen Auster (Ostrea edulis) und Möglichkeiten einer Wiederansiedlung in der Deutschen Nordsee. BfN, Bundesamt für Naturschutz.

Govindarajan, A.F., Carman, M.R., 2016. Possible cryptic invasion of the Western Pacific toxic population of the hydromedusa Gonionemus vertens (Cnidaria: Hydrozoa) in the Northwestern Atlantic Ocean. Biological invasions 18, 463-469.

Hadziavdic, K., Lekang, K., Lanzen, A., Jonassen, I., Thompson, E.M., Troedsson, C., 2014. Characterization of the 18S rRNA gene for designing universal eukaryote specific primers. PloS ONE 9, e87624.

Hagadorn, J.W., Dott, R.H., Damrow, D., 2002. Stranded on a Late Cambrian shoreline: Medusae from central Wisconsin. Geology 30, 147-150.

Helm, R.R., 2018. Evolution and development of scyphozoan jellyfish. Biol. Rev. 93, 12281250. 
293

294

295

296

297

298

299

300

301

302

303

304

305

306

307

308

309

310

311

312

313

314

315

316

317

318

319

320

321

322

323

324

325

326

327

328

329

330

Holst, S., 2012. Morphology and development of benthic and pelagic life stages of North Sea jellyfish (Scyphozoa, Cnidaria) with special emphasis on the identification of ephyra stages. Mar Biol 159, 2707-2722.

Holst, S., Jarms, G., 2010. Effects of low salinity on settlement and strobilation of scyphozoa (Cnidaria): Is the lion's mane Cyanea capillata (L.) able to reproduce in the brackish Baltic Sea? Hydrobiologia 645, 53-68.

Holst, S., Jarms, G., 2007. Substrate choice and settlement preferences of planula larvae of five Scyphozoa (Cnidaria) from German Bight, North Sea. Mar Biol 151, 863-871.

Holst, S., Laakmann, S., 2014. Morphological and molecular discrimination of two closely related jellyfish species, Cyanea capillata and C. lamarckii (Cnidaria, Scyphozoa), from the northeast Atlantic. J Plankton Res 36, 48-63.

Houziaux, J.-S., Fettweis, M., Francken, F., Van Lancker, V., 2011. Historic (1900) seafloor composition in the Belgian-Dutch part of the North Sea: a reconstruction based on calibrated visual sediment descriptions. Cont. Shelf Res. 31, 1043-1056.

Kawahara, M., Ohtsu, K. \& Uye, S. I. 2012. Bloom or non-bloom in the giant jellyfish Nemopilema nomurai (Scyphozoa: Rhizostomeae): roles of dormant podocysts. J. Plankt. Res., 35, 213-217.

Lucas, C.H., Graham, W.M., Widmer, C., 2012. Jellyfish Life Histories: Role of Polyps in Forming and Maintaining Scyphomedusa Populations. Adv Mar Biol 63, 133-196.

Makabe, R., Furukawa, R., Takao, M., Uye, S., 2014. Marine artificial structures as amplifiers of Aurelia aurita sl blooms: a case study of a newly installed floating pier. J. Oceanogr. 70, 447-455.

Morandini, A.C., Marques, A.C., 2010. Revision of the genus Chrysaora Péron \& Lesueur, 1810 (Cnidaria: Scyphozoa). Zootaxa 2464, 1-97.

Ludwig, W., Strunk, O., Westram, R., Richter, L., Meier, H., Buchner, A., Lai, T., Steppi, S., Jobb, G., Förster, W., others, 2004. ARB: a software environment for sequence data. Nucl. Acids Res. 32, 1363-1371.

Olsen, O.T., 1883. The Piscatorial Atlas of the North Sea, English and St. George's Channels: Illustrating the Fishing Ports, Boats, Gear, Species of Fish (how, where and when Caught), and Other Information Concerning Fish and Fisheries.

Perdon, K.J., Troost, K., van Zwol, J., van Asch, M., van der Pool, J., 2018. Schelpdierbestanden in de Nederlandse kustzone in 2018. Stichting Wageningen Research, Centrum voor Visserijonderzoek (CVO).

Schiariti, A., Morandini, A.C., Jarms, G., Paes, R. von G., Franke, S., Mianzan, H., 2014. Asexual reproduction strategies and blooming potential in Scyphozoa. Mar. Ecol. Prog. Ser. 510, 241-253. https://doi.org/10.3354/meps 10798

Schneider, C.A., Rasband, W.S., Eliceiri, K.W., 2012. NIH Image to ImageJ: 25 years of image analysis. Nat. Methods 9, 671-675. https://doi.org/10.1038/nmeth.2089 
331

332

333

334

335

336

337

338

339

340

341

342

343

344

345

346

347

348

349

350

351

352

353

Shibata, H., Miyake, H., Goto, T., Adachi, A., Toshino, S., 2015. Wild polyps of the blooming jellyfish Aurelia limbata (Brandt, 1838) (Cnidaria: Scyphozoa) found on deep-sea debris off Sanriku, Japan. Plankt. Benthos Res. 10, 133-140.

Stamatakis A. RAxML version 8: a tool for phylogenetic analysis and post-analysis of large phylogenies. Bioinformatics. 2014 May 1;30(9):1312-3. doi: 10.1093/bioinformatics/btu033. Epub 2014 Jan 21. PMID: 24451623; PMCID: PMC3998144.

Taylor, P.D., Wilson, M.A., 2003. Palaeoecology and evolution of marine hard substrate communities. Earth-Sci. Rev. 62, 1-103.

Thein, H., Ikeda, H. \& Uye, S.-I. 2013. Ecophysiological characteristics of podocysts in Chrysaora pacifica (Goette) and Cyanea nozakii Kishinouye (Cnidaria: Scyphozoa: Semaeostomeae): effects of environmental factors on their production, dormancy and excystment. J. Exp. Mar. Biol. Ecol., 446, 151-158.

Toyokawa, M., 2011. First record of wild polyps of Chrysaora pacifica (Goette, 1886)(Scyphozoa, Cnidaria). Plankt. Benthos Res. 6, 175-177.

Van der Baan, S.M., 1980. The seasonal occurrence of scyphomedusa in surface waters near the 'Texel' lightvessel. Intern Versl. NIOZ 1980-8.

Van Walraven, L., Driessen, F., van Bleijswijk, J., Bol, A., Luttikhuizen, P.C., Coolen, J.W., Bos, O.G., Gittenberger, A., Schrieken, N., Langenberg, V.T., Van der Veer, H.W., 2016. Where are the polyps? Molecular identification, distribution and population differentiation of Aurelia aurita. Mar Biol 163, 1-13.

Witbaard, R., Lavaleye, M., Duineveld, G., Bergman, M., 2013. Atlas of the megabenthos (incl. small fish) on the Dutch continental shelf of the North Sea (No. 2013-4), NIOZ rapport.

Peer] reviewing PDF | (2020:02:46309:1:1:NEW 8 May 2020) 
Figure 1

Generalised life cycle of metagenic scyphozoa.

Adult medusae $(A)$ reproduce sexually, producing planula larvae $(B)$ which settle on a substrate and either develop into a scyphistomae (C) or directly into a podocyst (D).

Scyphistomae can reproduce asexually by producing podocysts $(E)$, producing scyphistomae (F) or forming strobila $(\mathrm{G})$ which release ephyrae $(\mathrm{H})$ in a process called strobilation. Ephyrae develop into adult medusae.

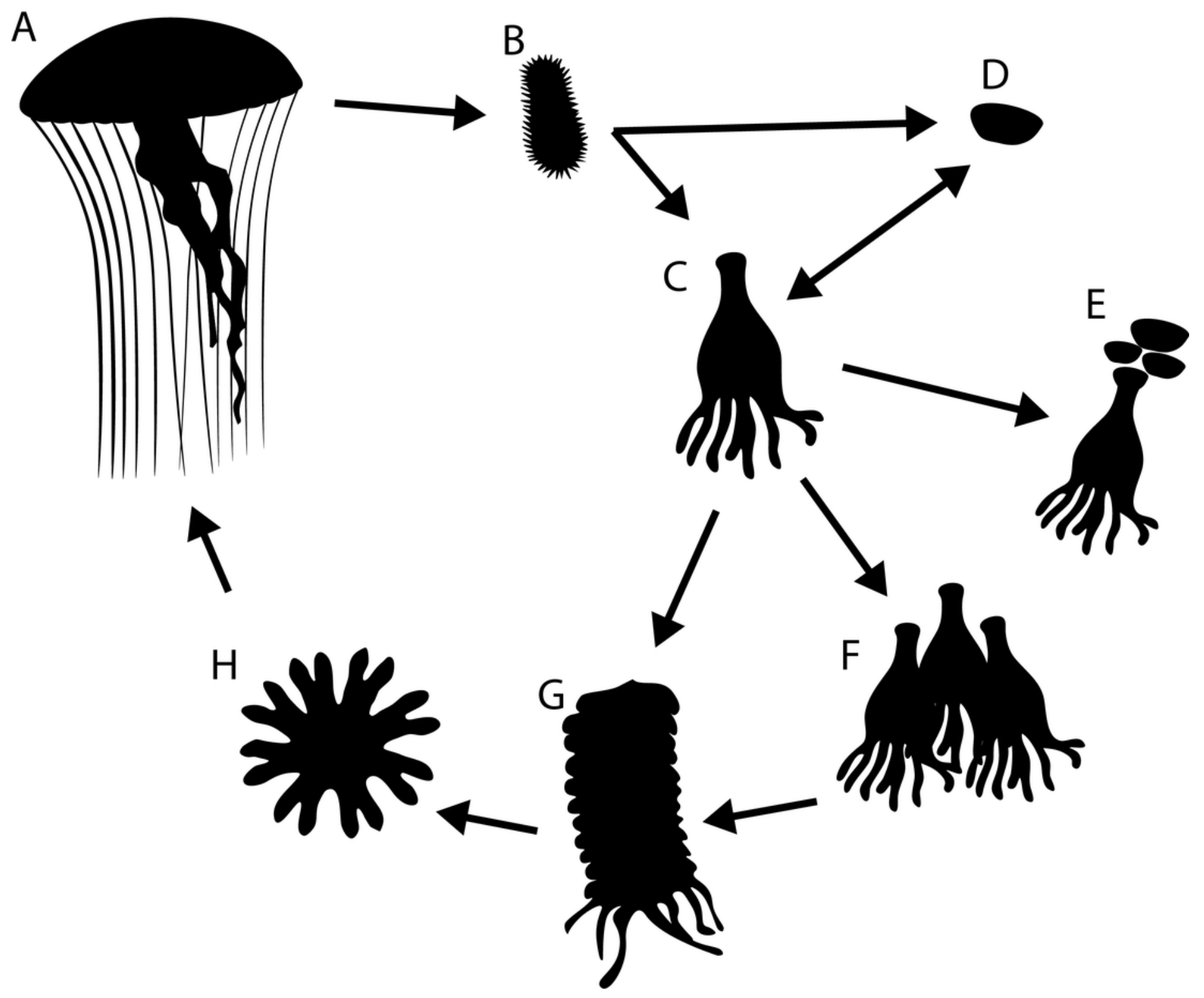


Figure 2

Transect of RV Pelagia cruise 64PE438

Red circles are sampling stations. The green stars show the location where polyps/podocysts were found: on the Doggerbank in the North Sea and on the beach of Oostende along the Belgian coast. Bathymetry layer provided by EMODnet (EMODnet Bathymetry Consortium (2016). 


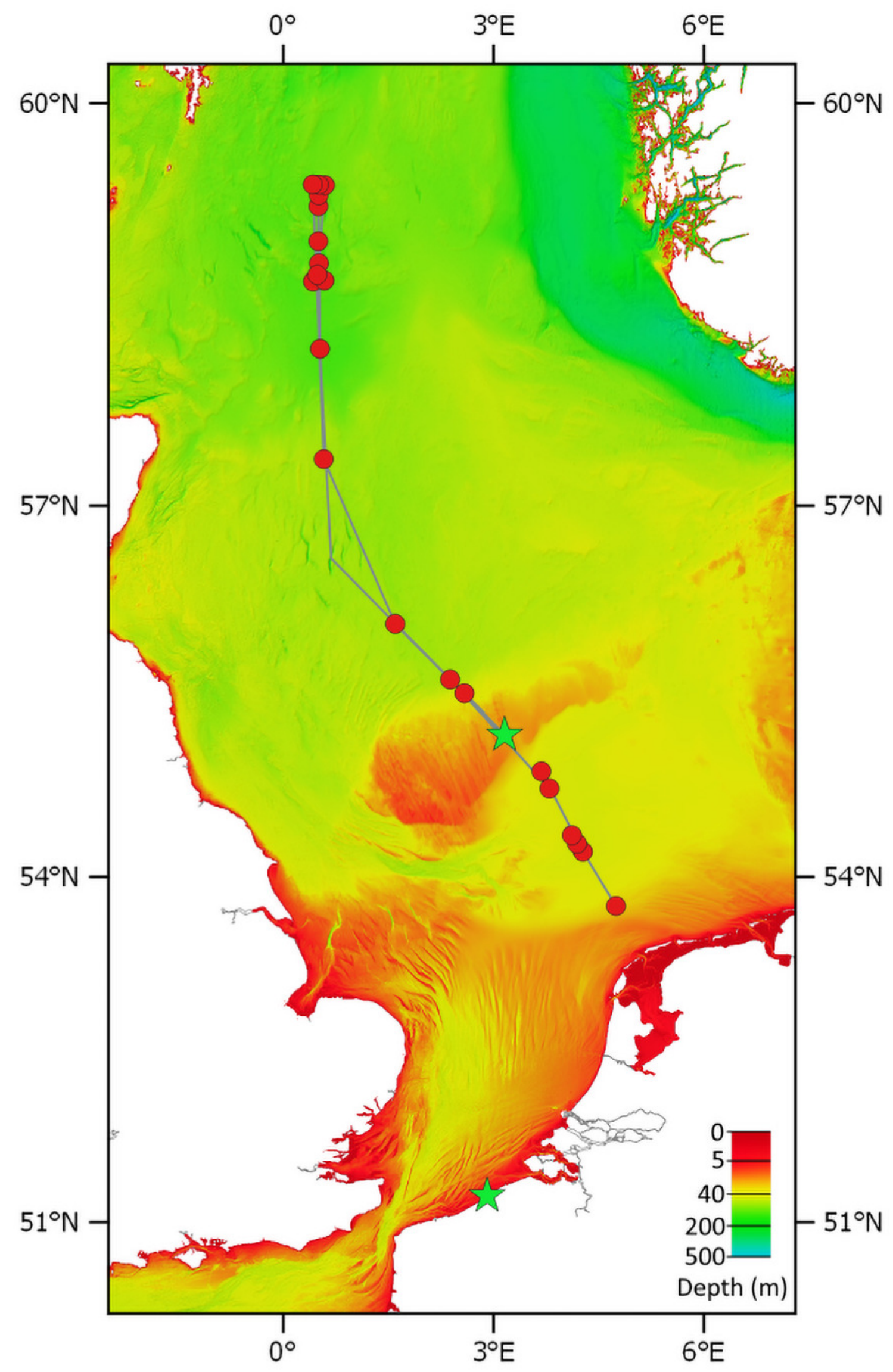




\section{Figure 3}

Detail of Mactra stultorum shell with attached Chrysaora hysoscella polyps and podocysts.

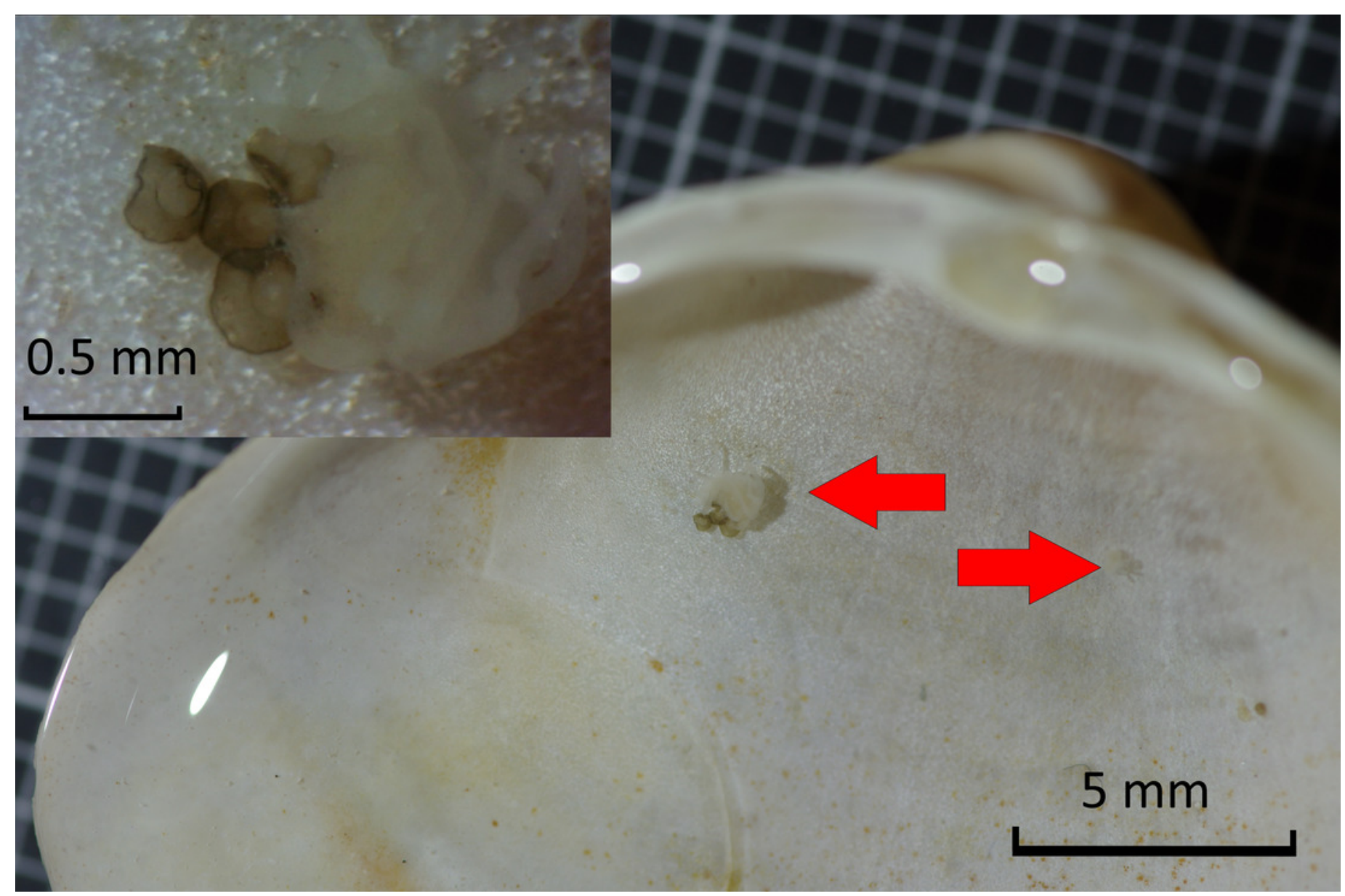




\section{Figure 4}

Photographs of podocyst clusters sampled for genetic analysis.

Several podocysts appeared empty, containing a circular hole in the centre, found in clusters A, E, G and J. Cluster G was identified as Cyanea lamarckii, cluster I was identified as Chrysaora hysoscella. All other clusters could not be identified by genetic analysis.
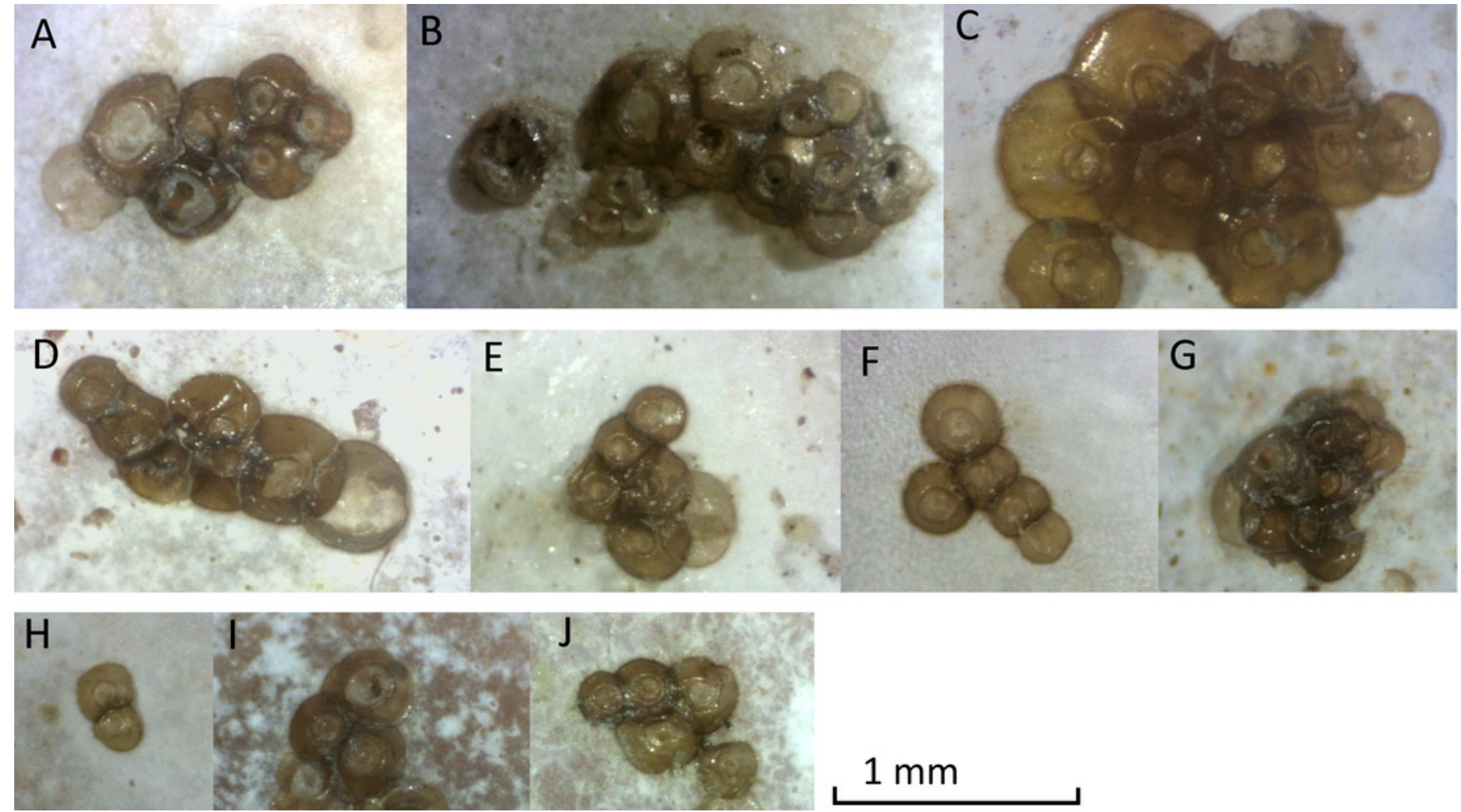


\section{Figure 5}

RAXML tree of jellyfish reference sequences obtained from GenBank (length 1573-1585 $\mathrm{nt}$ ), with newly obtained 18S rRNA V4-V5 sequences of polyps and podocysts (450 nt) added via ARB Parsimony.

The scale bar indicates the mean expected rates of substitutions per site. Newly added sequences are shown in italics. 
Chrysaora lactea, HM194810

Chrysaora sp. AGC-2005, AY920769, Chrysaora sp. AGC-2005 small s

Chrysaora hysoscella medusa, Texel beach, KT962259

NICO10_p1, MBJVB001, polyp on Spisula subtruncata

NICO10_p2, MBJVBO02, polyp on Mactra sultorum

NICO10_p3, MBJVBO03, polyp on Spisula subtruncata

cyste9LVW, MBJVBO09, podocyst on Cerastoderma edule

Cyanea lamarckii, NIOZ fish fyke, Texel, KT962255

Cyanea lamarckii, NIOZ fish fy
Cyanea lamarckii, JX995326

Cyanea lamarckii, JX995326

Cyanea capillata medusa, Gullmar Fjord, Sweden, KT962257

Cyanea capillata, JX995327

Aurelia aurita polyps from field, KT 962258

Aurelia aurita, U19541

Aurelia limbata, JX393277
Rhizostoma pulmo, HM194795

Rhizostoma octopus medusa, Wadden Sea, KT962256

Pelagia noctiluca, HE591464

Lucernaria janetae, AY845345, Lucernaria janetae small subun

- Haliclystus octoradiatus, AY845346, Haliclystus octoradiatus small

- Haliclystus sanjuanensis, AF358102, Haliclystus sanjuanensis small

0.10 
Figure 6

RAxML tree of jellyfish reference sequences obtained from GenBank (length 470-658 bp), with newly obtained COI sequences (518-610 nt) of polyps and podocysts added via ARB Parsimony.

The scale bar indicates the mean expected rates of substitutions per site. Newly added sequences are shown in italics. 


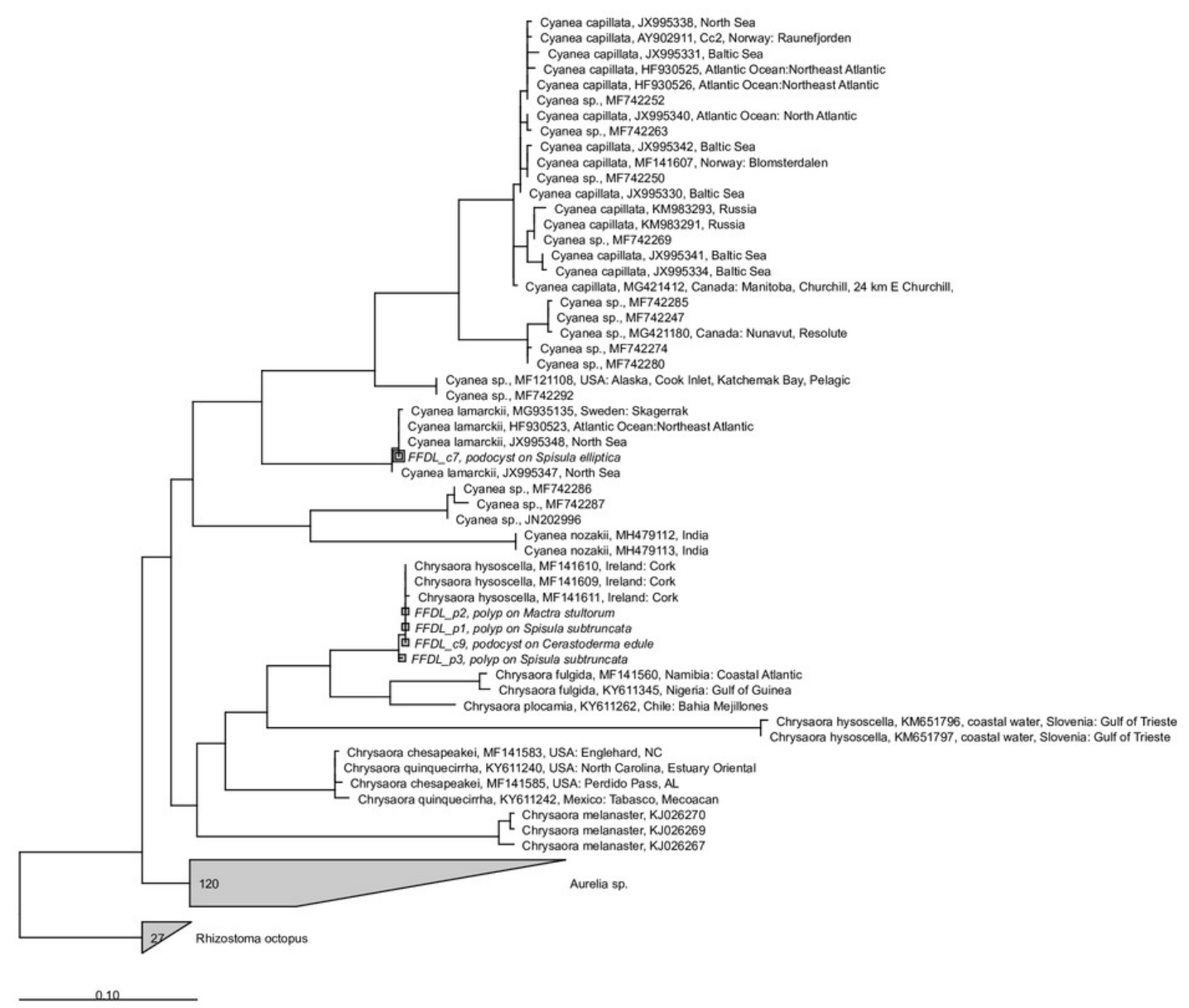




\section{Table $\mathbf{1}$ (on next page)}

Overview of samples from the two locations in the North Sea area included in genetic analyses.

P: polyps, C: podocyst. 
1 Table 1:

2 Overview of samples from the two locations in the North Sea area included in genetic analyses. P:

3 Polyp, C: podocyst.

4

\begin{tabular}{|c|c|c|c|c|c|}
\hline $\begin{array}{l}\text { Sample } \\
\text { name }\end{array}$ & Stage & location & date & host shell & ID \\
\hline NICO10_p1 & $\mathrm{P}$ & Dogger Bank & $25 / 05 / 2018$ & Spisula subtruncata & C. hysoscella (100\%) \\
\hline NICO10_p2 & $\mathrm{P} / \mathrm{C}$ & Dogger Bank & $25 / 05 / 2018$ & Mactra sultorum & C. hysoscella (100\%) \\
\hline NICO10_p3 & $P$ & Dogger Bank & $25 / 05 / 2018$ & Spisula subtruncata & $\begin{array}{l}\text { C. hysoscella (100\%) } \\
\text { Phoma sp. (Fungi, } \\
100 \%)\end{array}$ \\
\hline Cyste_1 & C & Oostende beach & $19 / 09 / 2018$ & Aequepecten opercularis & \\
\hline Cyste_2 & C & Oostende beach & $19 / 09 / 2018$ & Spisula subtruncata & $\begin{array}{l}\text { Pyropia sp. } \\
\text { (Rhodophyta, } 95 \% \text { ) }\end{array}$ \\
\hline Cyste_3 & C & Oostende beach & $19 / 09 / 2018$ & Spisula solida & failed \\
\hline Cyste_4 & C & Oostende beach & $19 / 09 / 2018$ & Mimachlamys varia & failed \\
\hline Cyste_5 & C & Oostende beach & $19 / 09 / 2018$ & Mimachlamys varia & failed \\
\hline Cyste_6 & C & Oostende beach & $19 / 09 / 2018$ & Spisula subtruncata & failed \\
\hline Cyste_7 & C & Oostende beach & $19 / 09 / 2018$ & Spisula elliptica & C. lamarckii (100\%) \\
\hline Cyste_8 & C & Oostende beach & 19/09/2018 & Donax vittatus & $\begin{array}{l}\text { Hydroides sp. } \\
\text { (Serpulidae, } 80 \% \text { ) }\end{array}$ \\
\hline Cyste_9 & C & Oostende beach & $19 / 09 / 2018$ & Cerastoderma edule & C. hysoscella (100\%) \\
\hline Cyste_10 & C & Oostende beach & $19 / 09 / 2018$ & Spisula subtruncata & failed \\
\hline
\end{tabular}

5

6 